\title{
Global Carbon Dioxide Removal Potential of Waste Materials From Metal and Diamond Mining
}

\author{
Liam A. Bullock ${ }^{1 * \dagger}$, Rachael H. James ${ }^{1}$, Juerg Matter ${ }^{1}$, Phil Renforth ${ }^{2}$ and \\ Damon A. H. Teagle ${ }^{1}$ \\ ${ }^{1}$ School of Ocean and Earth Science, National Oceanography Centre Southampton, University of Southampton, \\ United Kingdom, ${ }^{2}$ School of Engineering and Physical Sciences, Heriot-Watt University, Edinburgh, United Kingdom
}

OPEN ACCESS

Edited by:

Luca Riboldi,

SINTEF, Norway

Reviewed by:

Rafael Mattos Dos Santos,

University of Guelph, Canada

Patrick Frings,

German Research Centre for Geosciences, Helmholtz Centre

Potsdam, Germany

*Correspondence:

Liam A. Bullock

liam.bullock@eng.ox.ac.uk

${ }^{\dagger}$ Present address:

Liam A. Bullock,

Department of Engineering Science,

Parks Road, University of Oxford,

Oxford, United Kingdom

Specialty section:

This article was submitted to Negative Emission Technologies,

a section of the journal

Frontiers in Climate

Received: 12 April 2021

Accepted: 28 June 2021

Published: 28 July 2021

Citation:

Bullock LA, James RH, Matter J, Renforth P and Teagle DAH (2021)

Global Carbon Dioxide Removal

Potential of Waste Materials From

Metal and Diamond Mining.

Front. Clim. 3:694175.

doi: $10.3389 /$ fclim.2021.694175
There is growing urgency for $\mathrm{CO}_{2}$ removal strategies to slow the increase of, and potentially lower, atmospheric $\mathrm{CO}_{2}$ concentrations. Enhanced weathering, whereby the natural reactions between $\mathrm{CO}_{2}$ and silicate minerals that produce dissolved bicarbonate ions are accelerated, has the potential to remove substantial $\mathrm{CO}_{2}$ on decadal to centennial timescales. The global mining industry produces huge volumes of fine wastes that could be utilised as feedstock for enhanced weathering. We have compiled a global database of the enhanced weathering potential of mined metal and diamond commodity tailings from silicate-hosted deposits. Our data indicate that all deposit types, notably mafic and ultramafic rock-hosted operations and high tonnage Cu-hosting deposits, have the potential to capture $\sim 1.1-4.5$ Gt $\mathrm{CO}_{2}$ annually, between 31 and $125 \%$ of the industry's primary emissions. However, current knowledge suggests that dissolution rates of many minerals are relatively slow, such that only a fraction $(\sim 3-21 \%)$ of this potential may be realised on timescales of $<50$ years. Field trials in mine settings are urgently needed and, if this prediction is confirmed, then methodologies for accelerating weathering reactions will need to be developed.

Keywords: mine tailings, enhanced weathering, carbon dioxide removal, silicate minerals, Paris Agreement

\section{INTRODUCTION}

Anthropogenic inputs of carbon dioxide $\left(\mathrm{CO}_{2}\right)$ to the atmosphere are the primary cause of global warming (Field and Raupach, 2004; Canadell et al., 2007; IPCC, 2014). The Paris Agreement goal to limit the increase in global average temperature to $1.5^{\circ} \mathrm{C}$ is unlikely to be met without deep decarbonisation of the global economy together with large scale $\mathrm{CO}_{2}$ removal (CDR) from the atmosphere of up to $\sim 10$ gigatonnes $(\mathrm{Gt}) \mathrm{CO}_{2}$ per year (year ${ }^{-1}$ ) by 2050 , rising to $\sim 20 \mathrm{Gt}$ $\mathrm{CO}_{2}$ year $^{-1}$ by 2100 (UNEP, 2017; NASEM, 2019; Wilcox et al., 2021). This formidable challenge requires the urgent assessment of the full range of potential CDR approaches, as it is unlikely that any single technique will work at the scale required (e.g., Pacala and Socolow, 2004).

Enhanced weathering is a CDR strategy based on accelerating rock dissolution that sequesters $\mathrm{CO}_{2}$ through alkalinity production (Lackner et al., 1995; Hartmann et al., 2013; Renforth and Henderson, 2017; Alcalde et al., 2018; Andrews and Taylor, 2019; Li et al., 2019; Renforth, 2019; Beerling et al., 2020; Kelemen et al., 2020). The essence of the strategy is to mimic and accelerate natural chemical weathering, whereby minerals dissolve and react with atmospheric $\mathrm{CO}_{2}$ and water $(\mathrm{H} 2 \mathrm{CO} 3$ carbonic acid; reaction 1) to form bicarbonate solutions stabilised by solubilised cations (e.g., $\mathrm{Ca} 2+, \mathrm{Mg} 2+$; reactions 2 and 3). 
The dissolution products are subsequently transported to oceans by rivers. This natural process can be summarised as:

Dissolution of atmospheric $\mathrm{CO}_{2}: \mathrm{CO}_{2}+\mathrm{H}_{2} \mathrm{O} \rightleftharpoons \mathrm{H}_{2} \mathrm{CO}_{3}$ (1)

Carbonate rock and mineral weathering: $\mathrm{H}_{2} \mathrm{CO}_{3}+\mathrm{CaCO}_{3} \rightarrow$ $\mathrm{Ca}^{2+}+2 \mathrm{HCO}_{3}^{-}(2)$

Silicate rock and mineral weathering: $2 \mathrm{H}_{2} \mathrm{CO}_{3}+\mathrm{CaSiO}_{3} \rightarrow$ $\mathrm{Ca}^{2+}+2 \mathrm{HCO}_{3}^{-}+\mathrm{SiO}_{2}+\mathrm{H}_{2} \mathrm{O}(3)$

Thus, both carbonate and silicate weathering reactions consume $\mathrm{CO}_{2}$ and convert it to dissolved inorganic carbon (DIC), but silicate weathering consumes twice as much $\mathrm{CO}_{2}$ as carbonate weathering (reactions 2 and 3). Although we do not consider subsequent precipitation of secondary minerals here, it is important to note that precipitation of carbonates on land or in the ocean would result in release of some $\mathrm{CO}_{2}$ (reverse of reaction 2 ), effectively halving the net $\mathrm{CDR}$ for silicate weathering. Precipitation of other secondary minerals would also lower the efficacy of CDR. Natural weathering processes are slow, occurring over geologic timescales of tens of thousands of years, and the amount of $\mathrm{CO}_{2}$ taken up by weathering worldwide $\left(\sim 1.1 \mathrm{Gt} \mathrm{CO}_{2}\right.$ year $^{-1}$; Strefler et al., 2018) is a fraction of the annual increase in the atmospheric $\mathrm{CO}_{2}$ inventory ( $~ 8 \mathrm{Gt} \mathrm{CO}_{2}$ year $^{-1}$, Rapp, 2014). Removal of $\mathrm{CO}_{2}$ via enhanced weathering aims to accelerate the amount of natural chemical weathering by a factor of 2-10 such that in the next decades, significant quantities of $\mathrm{CO}_{2}$ can be removed from the atmosphere each year.

Mineral dissolution rates are in part controlled by the reactive surface area of mineral grains and the freshness of grain surfaces (Vance et al., 2009). Consequently, weathering rates can be increased through crushing and grinding. The mining industry extracts tens of Gt of rock material each year (Aachener Stiftung, 2011; Cherlet et al., 2018) that is crushed and ground to fine grainsizes $(10-1,000 \mu \mathrm{m})$, generating large amounts of freshly exposed reactive surface area that can increase mineral dissolution rates (Hitch et al., 2010; Pronost et al., 2011; Vogeli et al., 2011; Bodénan et al., 2014; McCutcheon et al., 2016; Li et al., 2018). As most common base metals (e.g., copper, lead, zinc, nickel) are profitably mined at concentrations as low as $\sim 1 \%$, precious metals [gold, silver, platinum group metals (PGMs)] at parts per million levels, and diamonds at 100s of parts per billion, most processed mine material is 'waste' and is stockpiled in dumps and tailings ponds. These mine tailings, the commercially uneconomic gangue material that remains following chemical and mechanical processing and separation of the economic fraction of the deposit, have been ground to clay-silt to sand-sized particles. Particles are subsequently mixed with water and process effluents to form slurries that accumulate in specialised storage facilities such as dams, dry stacks and underground containment areas. Depending on the targeted commodity, for every tonne of ore mined, proportionally 60 to $>99 \%$ of that ore becomes mine tailings (Ndlovu et al., 2017). Additionally, stripping ratios (whereby overburden rock is removed to access the ore rock) may produce up to an extra 16 tonnes of overburden for every one tonne of ore rock mined, although lower ratios (3:1 overburden to ore) are typically targeted by large open cast mining operations (Kay, 2018).

Annual $\mathrm{CO}_{2}$ equivalent $\left(\mathrm{CO}_{2} \mathrm{e}\right)$ emissions directly attributed to the metal and diamond industries are $\sim 3.6 \mathrm{Gt}$, based on 2018 data for production of primary minerals and metals (Azadi et al., 2020), and minor contributions ( $<3 \mathrm{Mt}$ total) from diamond mining ( $160 \mathrm{~kg} \mathrm{CO} \mathrm{CO}_{2}$ e per polished carat; S\&P Global, 2019; Statista, 2020), uranium mining (up to $50 \mathrm{t} \mathrm{CO}_{2} \mathrm{e}$ per $\mathrm{t}$ of $\mathrm{U}_{3} \mathrm{O}_{8}$; Mudd and Diesendorf, 2008; Statista, 2020) and olivine aggregate production used for slag conditioning $\left(\sim 55 \mathrm{~kg} \mathrm{CO} \mathrm{CO}_{2} \mathrm{e}\right.$ per $\mathrm{t}$ of olivine; Hangx and Spiers, 2009; Kremer et al., 2019). As global demand for metal, mineral and diamond resources continues to grow, it is imperative for the mining industry to reduce its carbon footprint (Mervine et al., 2018). Critically, the global mining industry is the only sector with the knowledge and equipment to redistribute and repurpose the huge quantities of materials required for $\mathrm{CDR}$ through enhanced weathering. If effective CDR schemes could be implemented at mine sites, combined with emissions reduction technologies, the carbon footprint of the mining industry would be greatly improved.

Here, we investigate the enhanced weathering potential and CDR capacity via alkalinity production of major metal, mineral and diamond commodity deposit types hosted by predominantly silicate rocks. We have assembled a global database of largescale commodity-hosting mine tailings. Our assessment does not include other types of unprocessed waste rock, such as stripped rocks or overburden, which is removed and piled without processing, or slag materials produced during smelting and refinement, although these may provide additional silicate rock masses that could have potential for enhanced weathering. We concentrate on silicate mineral-hosted commodity deposit types (Figure 1; Supplementary Material 1), although weathering of carbonate minerals and carbonate-hosting deposit types (e.g., limestone and marble quarries, Mississippi Valley Type $\mathrm{Pb}-\mathrm{Zn}$ deposits) will also consume $\mathrm{CO}_{2}$ (Kheshgi, 1995; Rau et al., 2007; Renforth et al., 2013), but is less efficient as only half of the alkalinity produced is derived from atmospheric $\mathrm{CO}_{2}$ (reaction 2). We assume that the ore-hosting phases such as sulphide minerals are largely removed from the silicate gangue during the commodity concentration process (e.g., up to $\sim 70-$ $90 \%$ ore recovery following beneficiation processes, McNab, 2006; Zanbak, 2012; Thenepalli et al., 2019; Zhang et al., 2020b).

Enhanced weathering potential and CDR capacity are calculated for each major deposit type from estimates of annual tailings production, and the mineralogical and geochemical compositions of the commodity-bearing rocks. We also assess the kinetics of mineral dissolution for implementation of CDR on a societal (i.e., Paris Agreement relevant) timescale (1100 years). This work extends previous studies that have focused on ultramafic-hosted deposits (e.g., Picot et al., 2011; Pronost et al., 2011; Vogeli et al., 2011; Meyer et al., 2014; Li et al., 2018; Renforth, 2019) and/or specific mine sites (e.g., Wilson et al., 2009; Power et al., 2013; Mervine et al., 2018) by (1) considering all major types of silicate rockhosted commodities and geological deposits, (2) estimating the CDR potential of given waste materials and sites, and (3) placing constraints on present and future tailings volumes. Our aim is to identify mine waste-types with the highest CDR potential to help prioritise engineering efforts for CDR via alkalinity generation. 


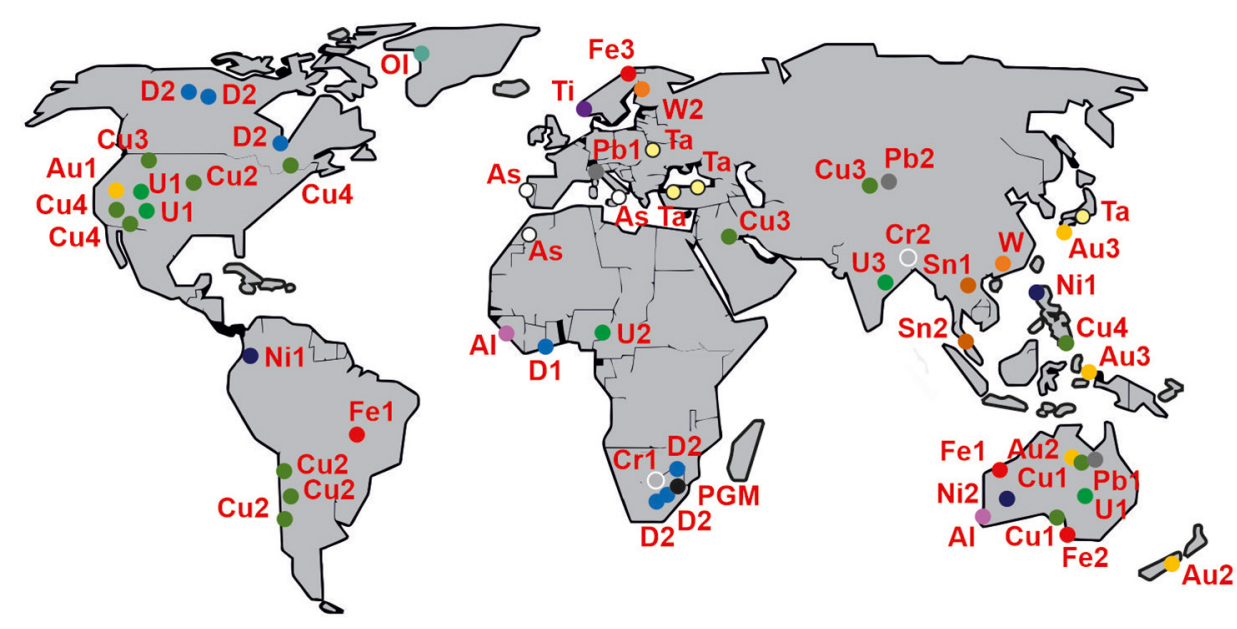

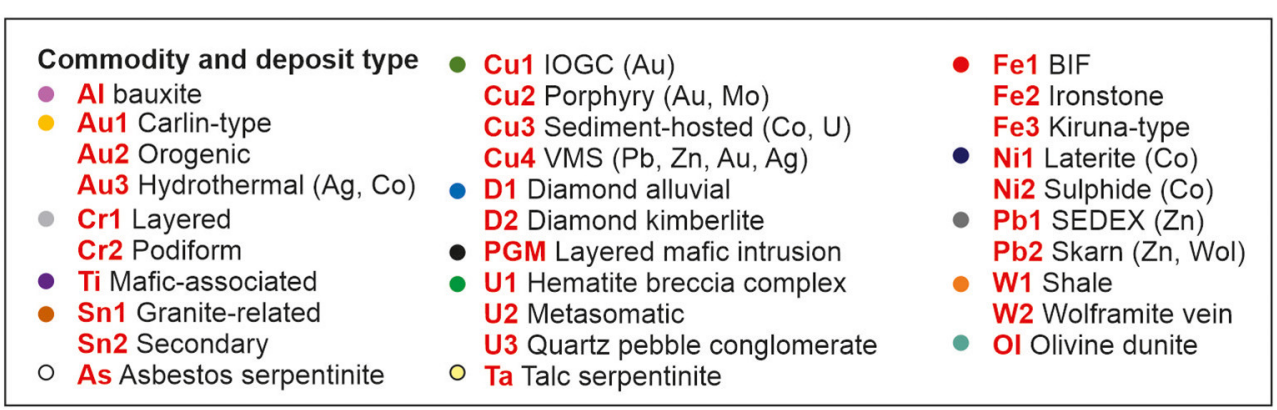

FIGURE 1 | Representative localities of the different mining commodity and deposit types examined in this study. See Supplementary Material $\mathbf{1}$ for general definitions, references and examples of selected deposit types.

\section{MATERIALS AND METHODS}

\section{Mine Tailings Production}

Annual tailings production $\left(\mathrm{ATP}_{\mathrm{X}}\right.$, in million tonnes per year, Mt year $^{-1}$ ) for each deposit type (Supplementary Material 1) has been estimated based on known ratios of commodity production to tailings production from published reports (see Supplementary Material 2). The proportional contribution of annual production of each commodity from different deposit types (e.g., how much of total global diamond production comes from kimberlite deposits and how much from alluvial deposits) has been estimated based on the information presented in Kesler and Simon (2015), Ndlovu et al. (2017) and U.S. Geological Survey mineral commodity summaries (USGS, 2021). Tailings production uncertainty was estimated based on the range of typical economic cut-off grades for each commodity sector (Supplementary Material 2). Estimates do not consider the effects of secondary targeted commodities (e.g., secondary chromite production at a PGM mine site).

\section{Enhanced Weathering Potential}

The chemical composition of targeted minerals and deposit types was determined from analyses of mineral compositions from 31 different large-scale mined deposit types and their associated targeted commodities (Figures 1, 2; Supplementary Materials 3-6). Exemplar deposits were selected based on the availability of geochemical data, with at least six analyses assessed for each deposit type to determine the range in chemical composition. In a few cases (e.g., $\mathrm{U}$ hematite breccia complex), analytical data are lacking or are poorly defined, and consequently single analyses were used. Exemplar deposits also targeted regions of large-scale active mining (Figure 1), except for mostly abandoned asbestos mines. The CDR potential through enhanced weathering and alkalinity production $\left(\mathrm{E}_{\text {pot }}, \mathrm{kg} \mathrm{CO}_{2} \mathrm{t}^{-1}\right)$ of mine waste material and the constituent minerals was calculated from the major element oxide concentrations of the mineral compositions (Supplementary Material 3-4) and bulk ore rocks (Supplementary Material 5-6), using a slightly modified version of the formulae described in Renforth (2019), based on Steinour (1959) (eqn 4):

$$
\begin{array}{r}
E_{p o t}=\frac{M_{\mathrm{CO}_{2}}}{100} \cdot\left(\alpha \frac{\mathrm{CaO}}{M_{\mathrm{CaO}}}+\beta \frac{\mathrm{MgO}}{M_{\mathrm{MgO}}}+\varepsilon \frac{\mathrm{Na}_{2} \mathrm{O}}{M_{\mathrm{Na}_{2} \mathrm{O}}}+\theta \frac{\mathrm{K}_{2} \mathrm{O}}{M_{\mathrm{K}_{2} \mathrm{O}}}\right. \\
\left.+\rho \frac{\mathrm{MnO}}{M_{\mathrm{MnO}}}+\gamma \frac{\mathrm{SO}_{3}}{M_{\mathrm{SO}_{3}}}+\delta \frac{P_{2} \mathrm{O}_{5}}{M_{\mathrm{P}_{2} \mathrm{O}_{5}}}\right) \cdot 10^{3} \cdot \eta(4)
\end{array}
$$


where $\mathrm{CaO}, \mathrm{MgO}, \mathrm{SO}_{3}, \mathrm{P}_{2} \mathrm{O}_{5}, \mathrm{MnO}, \mathrm{Na}_{2} \mathrm{O}$, and $\mathrm{K}_{2} \mathrm{O}$ are the respective elemental concentrations expressed as major element (wt\%) oxides, $\mathrm{M}_{\mathrm{x}}$ is the molecular mass of those oxides and $\eta$ is molar ratio of $\mathrm{CO}_{2}$ to cation sequestered during enhanced weathering. For silicate minerals, $\eta=2$ (Eq. 3), but here we use a conservative value of 1.5 to take into account buffering in the seawater carbonate system (Renforth and Henderson, 2017; Renforth, 2019).

The coefficients $\alpha, \beta, \gamma, \delta, \varepsilon, \theta$ and $\rho$ consider the relative contribution of each oxide to the enhanced weathering: $\alpha$ $=1$ for solutions $\mathrm{pH}<\sim 12, \beta=1$ for solutions $\mathrm{pH}<$ $\sim 10, \gamma=-1$ for solutions $\mathrm{pH}>3, \delta=-2, \varepsilon=1, \theta$ $=1$ and $\rho=1$ (Renforth, 2019). Coefficients may vary at extreme $\mathrm{pH}$ conditions (e.g., lower than 2 or higher than 12), but these are unlikely to be encountered in any atmospheric CDR scheme (Renforth, 2019). All carbonate was attributed to $\mathrm{CaCO}_{3}$. $\mathrm{Mg}$ may also be a major component of some carbonates, but the effect on $\mathrm{E}_{\text {pot }}$ is the same as for Ca. For deposit type $\mathrm{E}_{\text {pot }}$ calculations, the $\alpha$ value varies with carbonate content (and therefore $\mathrm{CaO}$ contribution) of the deposit. The coefficient for $\mathrm{Ca}(\alpha)$ was therefore adjusted for calculations of deposit types, based on the modal carbonate content of the rock. If the deposit type contains no carbonate, then $\alpha$ $=1$. However, if all $\mathrm{Ca}$ is hosted in carbonates, then $\alpha=$ $1 / 2$, because half of the alkalinity produced from weathering of the $\mathrm{Ca}$ is derived from carbonate, rather than $\mathrm{CO}_{2}$. The abundance of $\mathrm{Ca}$ associated with silicate or carbonate minerals was estimated from the modal mineralogy of the deposit type (Supplementary Material 5-6).

Weathering of S- and P-bearing minerals reduces the CDR potential $(\gamma=-1, \delta=-1.5)$ of ores because oxidative weathering acts to produce $\mathrm{CO}_{2}$ in the presence of carbonates (Torres et al., 2014; Renforth, 2019; Bufe et al., 2021). Although weathering of $\mathrm{Al}$ and $\mathrm{Fe}$ can generate alkalinity, these metals are not included in our $\mathrm{E}_{\text {pot }}$ calculations because $\mathrm{Al}$ and Fe form insoluble complexes with $\mathrm{OH}$ - in solution over $\mathrm{pH}$ ranges relevant to enhanced weathering, and consequently $\mathrm{Al}$ and $\mathrm{Fe}$ are rapidly removed from solutions by secondary mineral formation.

\section{RESULTS}

\section{Annual Tailings Production (ATPx)}

The total quantity of mine tailings material produced annually for the selected commodities and deposit types is estimated to be $\sim 13$ Gt year $^{-1}$ (mean quantity; range 9-17 Gt year ${ }^{-1}$; Supplementary Materials 2, 7). The largest producers of tailings material are associated with $\mathrm{Cu}$ (porphyry, VMS, sediment-hosted and IOGC deposits), Fe (banded iron formation (BIF), ironstone and Kiruna-type deposits) and $\mathrm{Au}$ (hydrothermal deposits) extraction (Figure 2B). Mining of $\mathrm{Cu}$ deposits produces the highest quantity of tailings, mean $\mathrm{ATP}_{\mathrm{X}}=\sim 10 \mathrm{Gt}$ year $^{-1}$. Other deposit types producing high quantities of tailings include $U$ hematite breccia complexes, Al bauxites, Ni sulphide deposits and PGM layered mafic intrusions. Deposits primarily producing $\mathrm{Pb}, \mathrm{Sn}, \mathrm{W}, \mathrm{Ti}$ and diamonds generally generate estimated $\mathrm{ATP}_{\mathrm{X}}$ quantities of $<20$ Mt year ${ }^{-1}$.

\section{$\mathrm{CO}_{2}$ Removal Potential $\left(\mathrm{E}_{\text {pot }}\right)$ of Mineral Phases and Deposit Types}

Mineral groups with the highest potential for sequestering $\mathrm{CO}_{2}$ are $\mathrm{Mg}-\mathrm{Fe}-\mathrm{Ca}$-bearing silicate minerals, including olivine (high forsterite olivine, Fo $_{88-100}$ ), serpentine (chrysotile, lizardite and antigorite), clinopyroxene (diopside and augite), orthopyroxene (enstatite and hypersthene) and amphibole (hornblende) (Figure 2A). Overall, pyroxene group minerals, which constitute a high modal abundance of many deposit types (Supplementary Material 5), span a range of $\mathrm{E}_{\text {pot }}$ values, from aegirine $\left(143 \mathrm{~kg} \mathrm{CO}_{2} \mathrm{t}^{-1}\right)$ to the $\mathrm{Mg}$-endmember enstatite $\left(658 \mathrm{~kg} \mathrm{CO}_{2} \mathrm{t}^{-1}\right)$. Other minerals with high $\mathrm{E}_{\text {pot }}$ include brucite, talc, clinochlore, phlogopite and wollastonite (see Supplementary Material 4). Brucite, a Mg-hydroxide mineral with a high $\mathrm{E}_{\text {pot }}$, has a $\mathrm{pH}$-dependent dissolution rate that is several orders of magnitude faster than olivine and serpentine group minerals (Harrison et al., 2013; Power et al., 2013, 2014, 2016; Wilson et al., 2014; McCutcheon et al., 2017; Li et al., 2018). Other common silicate minerals found within mine tailings such as feldspars (albite, anorthite and orthoclase) have modest $\mathrm{E}_{\text {pot }}$ values $\left(118-238 \mathrm{~kg} \mathrm{CO}_{2} \mathrm{t}^{-1}\right.$, with the highest value for Ca-rich anorthite; Figure 3), whereas minerals such as quartz, hematite, kaolinite and magnetite that are barren in readily soluble cations (e.g., $\mathrm{Na}, \mathrm{K}, \mathrm{Ca}, \mathrm{Mg}$ ) have no $\mathrm{CDR}$ potential. Minerals with high $\mathrm{Al}$ and $\mathrm{Fe}$ concentrations have low $\mathrm{E}_{\text {pot }}$ values, because of their tendency to form insoluble secondary minerals in the weathering environment (e.g., biotite and muscovite micas).

Calculated $\mathrm{E}_{\text {pot }}$ values reflect the ore host-rock geochemistry of the localities shown in Figure 1. However, deposit types have significant compositional variations, both within a specific locality and from region to region. The maximum and minimum $\mathrm{E}_{\text {pot }}$ values presented in Supplementary Material 6, 7 reflect these variations. The total annual removal potential for a commodity-hosting silicate deposit type is the product of the global annual tailings production $\left(\mathrm{ATP}_{\mathrm{X}}\right)$ and the enhanced weathering alkalinity potential of the ore-hosting rocks $\left(\mathrm{E}_{\text {pot }}\right)$. The cumulative sum for all deposit types is $\sim 2.4 \mathrm{Gt} \mathrm{CO}_{2}$ year ${ }^{-1}$ (based on mean $\mathrm{E}_{\text {pot }}$ and $\mathrm{ATP}_{\mathrm{X}}$ ), with an overall range of 1.1-4.5 Gt $\mathrm{CO}_{2}$ year $^{-1}$ due to variations in geochemistry and economic cut-off grades. It follows that commodity-hosting deposit types hosting high abundances of $\mathrm{Ca}-\mathrm{Mg}$ bearing silicate minerals (and minor amounts of brucite) have the highest potential for CDR per $\mathrm{Mt}$ of tailings (Figure 2B). These deposits include talc and asbestos-hosting serpentinites, olivine-rich dunites, magmatic Ni sulphides, kimberlites, skarns, layered mafic intrusions and podiform type deposits. These deposits are typically formed as mafic and ultramafic magmas, as derivatives of magmatic processes in mafic and ultramafic rocks, or as later alteration products. Consequently, they have high modal abundances of potentially reactive primary and secondary silicates, including olivine, pyroxene (particularly diopside and enstatite), serpentine, amphibole and chlorite. Some of these 
A

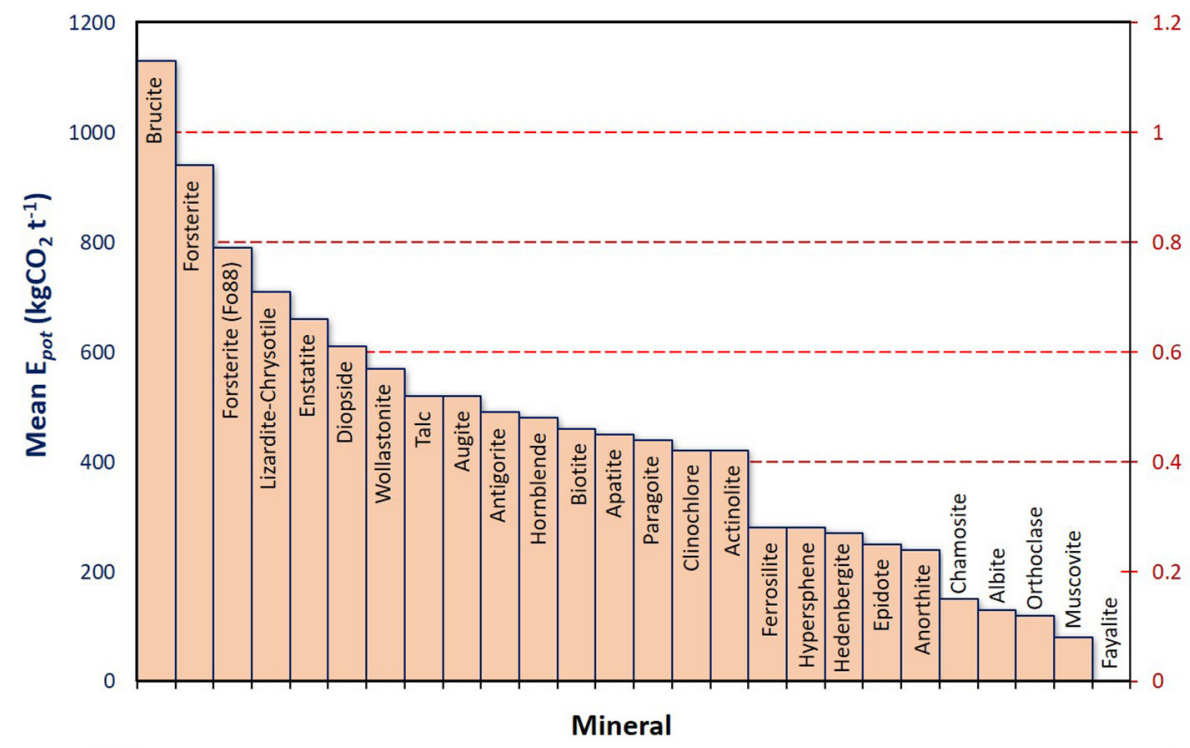

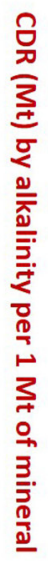

B

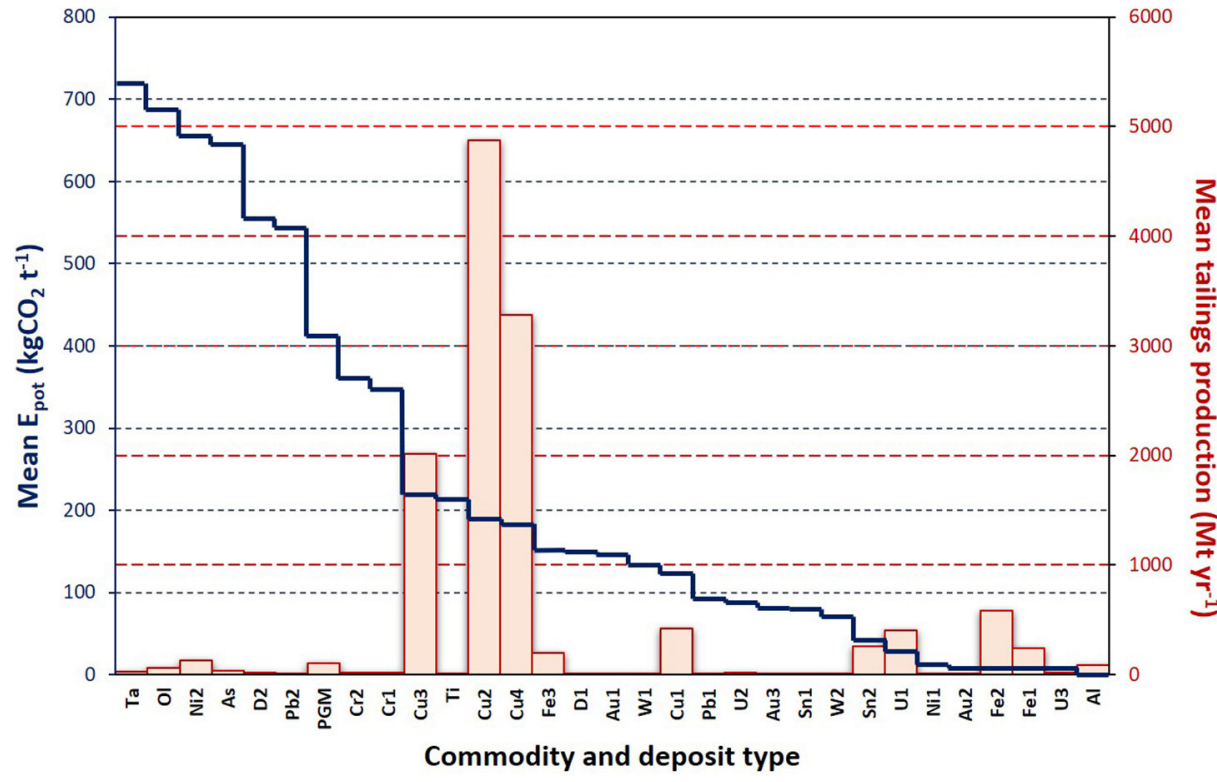

\begin{tabular}{|c|c|c|}
\hline Ta - Talc serpentinite & Cu2 - Cu porphyry & W2 - W Wolframite vein \\
\hline Ol-Olivine dunite & Cu4-Cu VMS & Sn2-Sn Secondary \\
\hline Ni2 - Ni sulphide & Fe3 - Fe Kiruna-type & U1 - U Hematite breccia complex \\
\hline As - Asbestos serpentinite & D1 - Diamond alluvial & $\mathrm{Ni} 1-\mathrm{Ni}$ Laterite \\
\hline D2 - Diamond kimberlite & Au1 - Au Carlin-type & Au2 - Au Orogenic \\
\hline $\mathrm{Pb} 2-\mathrm{Pb}-Z n$ skarn & W1 - W Shale & Fe2 - Fe Ironstone \\
\hline PGM - PGM Layered mafic intrusion & Cu1 - Cu IOGC & $\mathrm{Fe} 1-\mathrm{Fe} \mathrm{BIF}$ \\
\hline $\mathrm{Cr} 2-\mathrm{Cr}$ podiform & Pb1 - Pb-Zn SEDEX & U3 - U Quartz pebble conglomerate \\
\hline $\mathrm{Cr} 1-\mathrm{Cr}$ layered mafic intrusion & U2 - U Metasomatic & Al-Al bauxite \\
\hline Cu3 - Cu sediment-hosted & Auz - Au-Ag Hydrothermal & \\
\hline $\mathrm{Ti}-\mathrm{Ti}$ mafic-associated & Sn1-Sn Granite-related & \\
\hline
\end{tabular}

FIGURE 2 | Production tonnages and enhanced weathering potential $\left(E_{p o t}\right)$ of deposit types and associated common rock-forming minerals. (A) Calculated $E_{p o t}$ of common minerals and major gangue minerals likely to be present in tailings. $\mathrm{CO}_{2}$ captured as alkalinity per $1 \mathrm{Mt}$ of each mineral also shown. (B) Mean $\mathrm{E}_{\text {pot }}$ values of commodity-hosting deposit types (blue line) and mean estimated tailings production (red bars) from major commodity-hosting deposit types. Data and explanation of abbreviations are provided in Supplementary Material 3-6. 


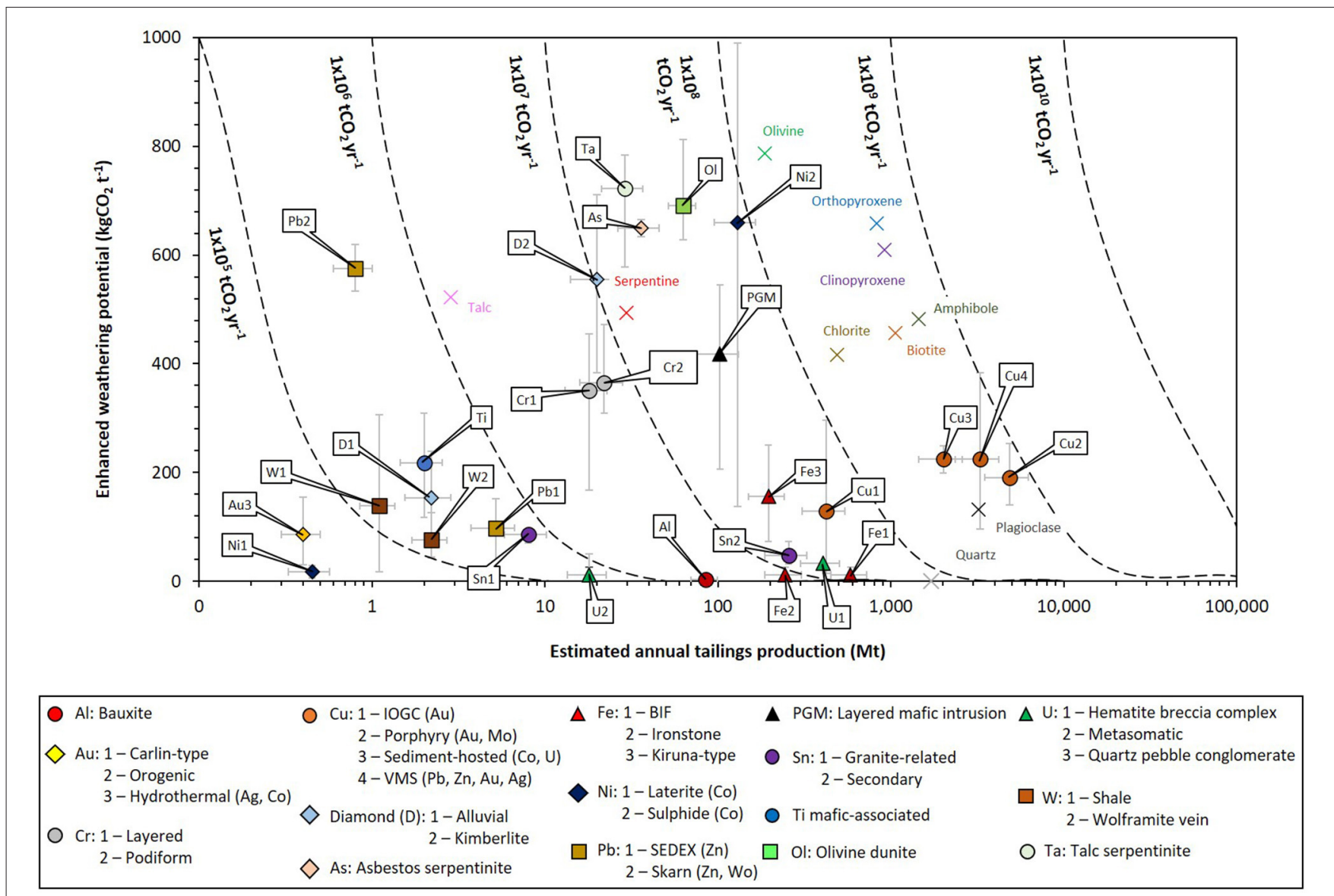

FIGURE 3 | Calculated $E_{p o t}$ values (with error bars accommodating variations in geochemical composition) vs. estimated mean ATPx (error bars based on variations in economic cut-off grades) for commodity-hosting silicate deposit types. Contours show $\mathrm{CO}_{2}$-capture in $\mathrm{tCO}_{2}$ year-1 . Typical gangue minerals also shown (based on estimated abundances in deposit types).

deposits contain minor amounts of highly reactive brucite. Deposits that contain high quantities of felsic minerals, such as quartz or alkali feldspar-rich deposits, those that contain high proportions of sulphide minerals and those that are barren in high Ca-Mg-bearing minerals, have low CDR potential. Deposit types that have highly variable whole rock compositions or which may have undergone alteration (e.g., carbonation), such as some dunites, $\mathrm{Ni}$ sulphides and kimberlites, have a wide range of $\mathrm{E}_{\text {pot }}$ values (Figure 3). Importantly, due to the high production tonnages (mean tonnages $>2 \mathrm{Gt} \mathrm{year}^{-1}$ ), deposit types such Cu-hosting porphyry, VMS and sedimenthosted deposits with only moderately high $\mathrm{E}_{\text {pot }}$ values (129$224 \mathrm{~kg} \mathrm{CO}_{2} \mathrm{t}^{-1}$ ), still have high CDR capacities (Figure 3). The calculated $\mathrm{E}_{\text {pot }}$ values indicate that deposits such as bauxite, BIF and ironstone are chemically unfavourable for enhanced weathering as they are high in $\mathrm{SiO}_{2}$ - and $\mathrm{Fe}_{2} \mathrm{O}_{3}$-rich minerals but low in $\mathrm{MgO}$ and $\mathrm{CaO}$. Consequently, although there are large quantities of mine wastes generated by BIF and ironstone mining, their enhanced weathering potential is low.

\section{DISCUSSION}

\section{Global $\mathrm{CO}_{2}$ Removal Potential of Mine Waste Material}

Our best estimate for the annual potential for CDR by enhanced weathering of silicate mine tailings through the generation of alkalinity is $\sim 2.4 \mathrm{Gt} \mathrm{year}^{-1}$ (range 1.1-4.5 Gt $\mathrm{CO}_{2}$ year $^{-1}$ ). Global mining operations are estimated to emit up to $\sim 3.6 \mathrm{Gt}^{\mathrm{CO}_{2} \mathrm{e} \text { year }}{ }^{-1}$ from extraction and processing (Azadi et al., 2020). Consequently, enhanced weathering of mine tailings has the potential to make a significant contribution to the industry's net-zero ambitions. If the mining industry were to pursue far-reaching decarbonisation through the comprehensive deployment of renewable energy, electrification and improved efficiencies, then enhanced weathering of wastes could be a major contributor of negative carbon emissions and potentially accommodate a significant portion of the $\sim 10 \mathrm{Gt} \mathrm{CO}_{2}$ year ${ }^{-1}$ (IPCC, 2014) reductions required to meet the 2050 Paris Agreement climate targets. 
Increasing demand for certain metals due to economic growth and resource requirements for new green technologies means that deposits associated with important industrial commodities such as $\mathrm{Ni}, \mathrm{Zn}, \mathrm{Fe}, \mathrm{Co}, \mathrm{Cu}, \mathrm{Cr}$, Ti, PGMs and rare earth elements are likely to grow over the next 10 years (World Bank Group, 2017; Pariser et al., 2018; Supplementary Material 8) with consequent increases in tailings production. Projected market growth for commodities such as $\mathrm{Ni}$ (market estimated to rise by $4.5 \%$ between 2018 and 2030; Mining Technology, 2019), W (estimated market growth $4.2 \%$ between 2019 and 2030; Freedonia, 2019) and Cr (estimated market growth 3.5\% between 2018 and 2030; KPMG, 2018) mean that the $\mathrm{ATP}_{\mathrm{X}}$ associated with these deposit types will likely increase. We estimate that, if market growth follows projected trends, the mining industry could remove an additional $\sim 280 \mathrm{Mt} \mathrm{CO}_{2}$ by 2030 (see Supplementary Material 8). Future production at lower operational cut-off grades, and consequently high gangue to ore ratios, due to anticipated improvements in extractive technologies and increased market demand would further increase the CDR potential of the mining industry.

In addition, many mining operations host very large volumes of historic tailings that have accumulated over many decades. As historic tailings are often stored at mine sites for future resource extraction (at lower grades), future processing of these tailings also presents an opportunity for additional CDR. Effective utilisation of historic mine tailings for enhanced weathering may increase the CDR capacity by several orders of magnitude. Furthermore, there are other waste streams associated with the mining, processing and production of metals and diamonds that may have additional CDR potential. For example, blast furnace slags, formed as a by-product of Fe production after the additions of magnesia and lime fluxes (e.g., forsterite and magnesite), consist of crystallised $\mathrm{Ca}-\mathrm{Al}-\mathrm{Mg}$ silicates, with physicochemical properties similar to crushed natural basalt (Horii et al., 2013; Ndlovu et al., 2017). Ferrochromium smelter dusts and slags, which have also been fluxed with silica, lime and/or dolomite, consist of partly crystalline forsterite, pyroxene and $\mathrm{Mg}$-spinel phases (Hayhurst, 1974; Sedumedi et al., 2009; Ndlovu et al., 2017).

Favourable mine sites for CDR are distributed across the globe (Supplementary Material 9 and Supplementary Figure 9), noting that there is a lack of information (mine sites and production estimates) for areas of northern and eastern Asia that are known to host favourable sites. For instance, areas of Russia and China host significant PGM, nickel, diamond, talc, asbestos and olivine resources (according to national reports cited in USGS mineral commodity summaries), but detailed site information is scarce. Site examples and reliable estimates of wollastonite and brucite production are also limited for most countries. Where site information is available, parts of the western United States, eastern and north-western Canada, Southern Africa, western Australia, the South American Andes and southern Europe all show multiple possible implementation sites.

\section{Efficacy of Enhanced Weathering of Mine Wastes}

The enhanced weathering and alkalinity production potential $\left(\mathrm{E}_{\text {pot }}\right)$ only estimates the hypothetical maximum CDR capacity of mine wastes. It assumes $100 \%$ mobilisation of fluid soluble cations from waste minerals with the consequent production of alkalinity. It takes no account of reaction kinetics and hence it is imperative to also consider the timescales of mineral dissolution. Dissolution rates are mineral specific and remain poorly known. Estimates often span many orders of magnitude and are strongly dependent on environmental conditions such as temperature, biological activity and $\mathrm{pH}$, with rates tending to minima at near neutral $\mathrm{pH}(\mathrm{pH} \sim 5.6-8.2$, Palandri and Kharaka, 2004; Bandstra et al., 2008). Furthermore, mineral dissolution rates calculated from catchment-scale field studies are two to five orders of magnitude slower than experimental mineral dissolution rates that are usually determined under far-from-equilibrium conditions (e.g., White et al., 1996). Although microbial, fungal and other biological activities are expected to develop micro-environments that increase mineral dissolution rates, secondary coatings on weathered mineral surfaces mean that dissolution rates decrease dramatically with soil age following a power-law relationship (e.g., Vance et al., 2009). Reaction rates increase with increasing reactive surface area exposed by finer particle sizes. The fresh mineral surfaces generated by crushing and grinding during ore beneficiation should mean that mine wastes weather more quickly than in situ geological materials or soils. Consequently, it is reasonable to apply the higher estimates of mineral dissolution rates to mine waste studies.

Simple shrinking core modelling of mineral dissolution indicates that for typical grainsizes of mine tailings $(\sim 50-$ $500 \mu \mathrm{m}$; Lapakko et al., 2006; Koomson and Asiam, 2013; Ndlovu et al., 2017; Zhang et al., 2020a), relatively fast mineral dissolution rates $\left(\mathrm{W}_{\mathrm{r}}\right)$ of greater than $\sim 10^{-9}-10^{-10} \mathrm{~mol} \mathrm{~m}^{-2}$ $\mathrm{s}^{-1}$ are required for near complete weathering of mine waste minerals on reasonable societal timescales of years to decades (Figure 4). However, estimated particle dissolution times are strongly dependent on grain size distributions and specific surface area (Gbor and Jia, 2004), and empirical studies with actual mine tailings are required to verify estimates. If current estimates of mineral dissolution rates are representative of actual mine waste, then this would restrict enhanced weathering of mine waste to a limited number of gangue minerals such as olivine, brucite and wollastonite, even for the most optimistic (highest) values of $\mathrm{W}_{\mathrm{r}}$. These minerals are minor constituents of mine waste and only contribute up to $\sim 21 \%$ (mean $8 \%$ ) of the estimated global CDR potential of mine wastes. Other major gangue mineral groups with high to moderate enhanced weathering potential such as pyroxenes, amphiboles, serpentine, chlorites and feldspars that make up the bulk of mine tailings, have mineral dissolution rates of less than $10^{-10} \mathrm{~mol} \mathrm{~m}^{-2} \mathrm{~s}^{-1}$ at near neutral $\mathrm{pH}$ (Palandri and Kharaka, 2004; Bandstra et al., 2008) and would require decades to millennia to react (e.g., Figure 4). Given that most tailings are mixtures of minerals, with some including 

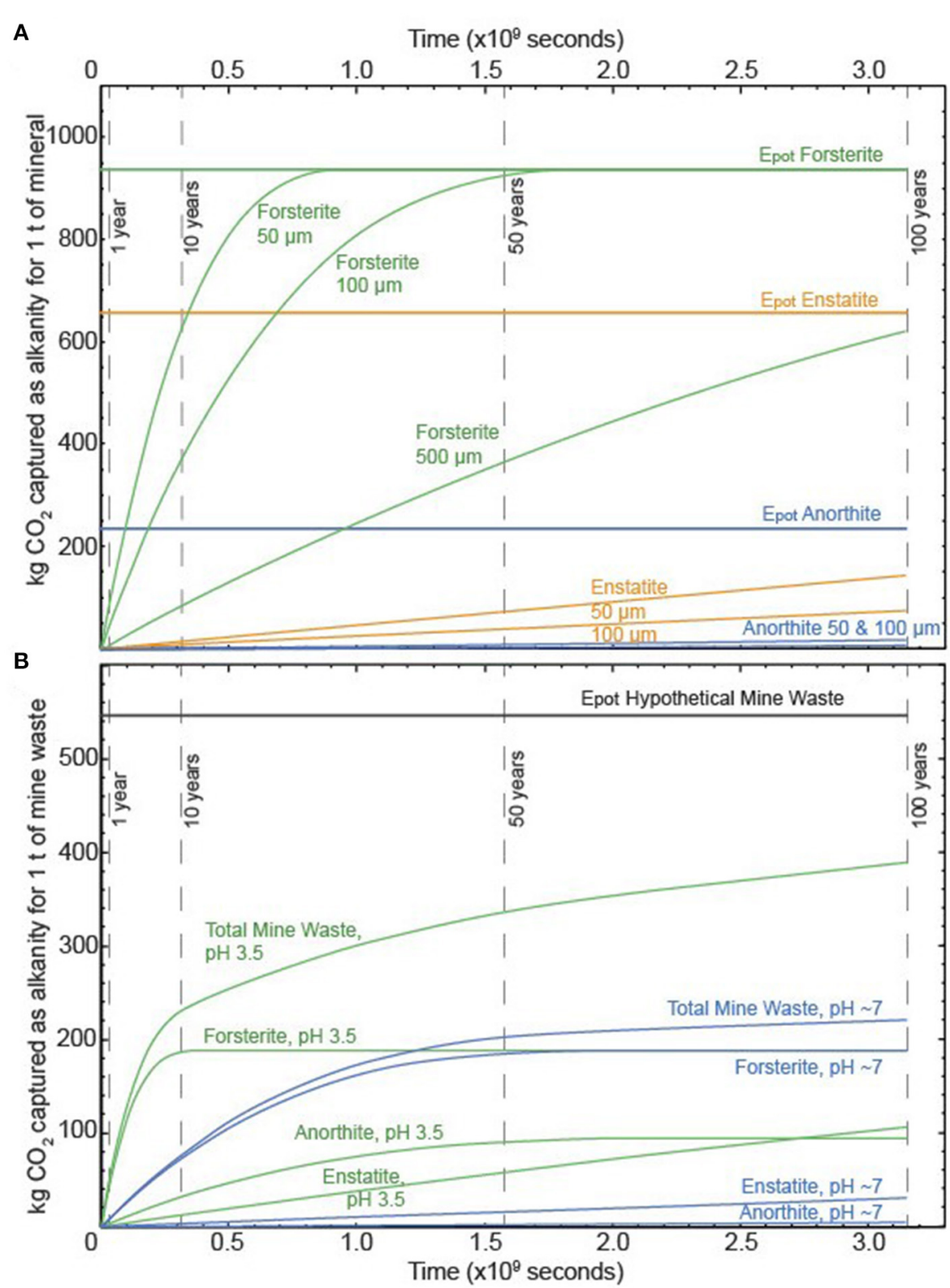

FIGURE 4 | Alkalinity production through enhanced weathering of selected minerals and mine waste with time. (A) Cumulative CDR by weathering in ambient $\left(\sim 25^{\circ} \mathrm{C}\right)$ near-neutral $\mathrm{pH}$ conditions ( $\mathrm{pH} \sim 7$ ) for olivine $\mathrm{Mg}$-end member forsterite ( $\mathrm{Fo}$ ), orthopyroxene Mg-end member enstatite (En), and plagioclase Ca-end member anorthite (An) as these are common minerals in some major ore types such as $\mathrm{Cr}$ and PGM deposits. End member compositions are used because experimental dissolution rates are available for these phases. We acknowledge that solid solutions to iron-bearing mafic minerals and sodic feldspars are most commonly present in nature. The $\mathrm{E}_{\text {pot }}$ for each mineral was calculated using Eq. 5, and dissolution time trajectories calculated using a shrinking grain model (following Kelemen et al., 2020) for $1 \mathrm{t}$ of mineral of a uniform grainsize $(50,100$ and $500 \mu \mathrm{m})$ using $W_{r}$ for near-neutral $\mathrm{pH}$ conditions $\left(\log \mathrm{W}_{\mathrm{r}}^{\mathrm{Fo}}=-9.3 ; \mathrm{W}_{\mathrm{r}}^{\mathrm{En}}=-11 ; \mathrm{W}_{\mathrm{r}}^{\mathrm{An}}=-12\right.$, after Bandstra et al., 2008). Finer grains dissolve more quickly and alkalinity production would increase by approximately one order of magnitude if a more realistic grainsize distribution is used (as shown in Kelemen et al., 2020). Only relatively fine-grained olivine (100 $\mu \mathrm{m}$ or less) weathers completely on decadal time scales ( $<50$ years). (B) Cumulative CDR by enhanced weathering in ambient $\left(\sim 25^{\circ} \mathrm{C}\right)$ conditions of $1 \mathrm{t}$ of hypothetical mine waste comprising $100 \mu \mathrm{m}$ grains of $20 \% \mathrm{Fo}, 40 \%$ En and $40 \%$ An, which is representative of mafic rocks that host $\mathrm{Cr}$ and PGM deposits. At near-neutral conditions (blue lines) olivine (Fo) dissolution provides $\sim 85 \%$ of the alkalinity with only minor contribution from En, and there is only a very slow increase in alkalinity after 50 years due to the exhaustion of the Fo reservoir. At more acidic, $\mathrm{pH}=3.5$ conditions (green lines), as might be achieved by $\mathrm{CO}_{2}$-saturated water, reaction rates are significantly increased, all available $\mathrm{Fo}$ is consumed within 10 years (log $\mathrm{W}_{\mathrm{r}}^{\mathrm{FO}}$ $=-8.5)$, and An weathering is complete in $\sim 50$ years $\left(\log W_{r}^{A n}=-10\right)$. Pyroxene dissolution rates are poorly determined and highly variable (Bandstra et al., 2008) with experiments to date suggesting only a slight increase in dissoluton rates $\left(\log W_{r}^{E n}=-10.4\right)$ for $\mathrm{pH} 3.5$. Consequently, for this hypothetical mixture, almost $30 \%$ of the potential alkalinity is unrealised even after 100 years. 
phases such as olivine, pyroxene and feldspar (e.g., $\mathrm{Cr}$ and PGE deposits), this would suggest that for a specific batch of mine tailings, less than half of the full CDR potential of the tailings would be realised within 50 years (at $\mathrm{pH} \sim 7$; Figure 4B).

Clearly there is a need for better understanding of mine waste weathering through demonstrator scale field experiments using actual wastes in local conditions. Nevertheless, it is almost certain that new approaches will need to be developed to greatly accelerate mineral dissolution rates $\left(\mathrm{W}_{\mathrm{r}}\right)$ to harness the full potential of mine waste as a feedstock for CDR. This is especially pertinent for high tonnage $\mathrm{Cu}$ operations and $\mathrm{Cr}$ and PGM deposits that are rich in feldspars and/or pyroxenes that weather relatively slowly. Demonstrator scale experiments will need to adjust for climatic and environmental conditions, geography and availability of critical resources such as water and space. To date, field- and laboratory-based experiments with a focus on accelerating the weathering of mine waste minerals and rocks are limited and generally restricted to ultramafic host rocks (e.g., Harrison et al., 2013; Power et al., 2013, 2014, 2016; Wilson et al., 2014; McCutcheon et al., 2016; Mervine et al., 2018).

Solutions to improve the efficacy of weathering of mine wastes take two forms: (a) approaches to increase $\mathrm{W}_{\mathrm{r}}$, and (b) engineering techniques that maximise the exposure of waste materials to the atmosphere or reacting agents. Reaction kinetics can be accelerated through reaction with $\mathrm{CO}_{2}$-rich fluids and gases (Huntzinger et al., 2009; Harrison et al., 2013; Marieni et al., 2020), addition of water and heat (Martinez et al., 2000; Zevenhoven and Kohlmann, 2001), the addition of organic and inorganic acids (Azdarpour et al., 2015; McCutcheon et al., 2015, 2016, 2017; Power et al., 2016; Li et al., 2018), and techniques exploiting microbial metabolisms (Salek et al., 2013; Power et al., 2015, Power et al., 2020) that push local reaction environments away from the slowest near $\mathrm{pH}$ neutral conditions. For example, carbon capture rates of brucitecontaining Ni sulphide tailings were increased 5-fold by aerating tailings with $10 \% \mathrm{CO}_{2}$ gas (Power et al., 2020), with a $\sim 2400$-fold acceleration for pure $\mathrm{CO}_{2}$ (Harrison et al., 2013). The addition of bovine carbonic anhydrase enzymes greatly accelerated $(>2 \times)$ reactions with brucite ores (Power et al., 2016).

Presently, mine tailings storage facilities are engineered to maximise safe storage for a particular unit area, resulting in thick $(\sim 10 \mathrm{~s}$ of $\mathrm{m})$ piles of rapidly accumulated tailings. These sediments are typically of silt to fine sand grainsize $(\sim 4-250 \mu \mathrm{m})$ and often ground to restricted grain-size ranges for specific ore treatments. Consequently, due to the monotony of particle size, both active and historic tailing stacks often have relatively low interconnected porosities limiting the exposure of reactive surfaces to $\mathrm{CO}_{2}$-charged fluids and the atmosphere. This could be improved by mixing waste tailings with other less finely ground material (e.g., discarded overburden material) optimised to promote interconnected porosity. Accumulation rates of tailings could also be modified to allow more time for reactions to occur before reactive materials are buried beyond the active weathering horizon (e.g., Wilson et al., 2014), but this requires more tailings ponds and proportionally larger areas to store the wastes.

A related approach is to widely spread tailings over agricultural or other land (e.g., Corti et al., 2012; Edwards et al., 2017). An annual application rate of $\sim 40 \mathrm{t} \mathrm{ha}^{-1}$ of basalt, which is compositionally similar to some tailings generated from PGM, $\mathrm{Cr}$ and $\mathrm{Ni}$ mines, has been suggested as an effective additive to improve soils (Beerling et al., 2020). Similar agricultural and coastal spreading approaches have been proposed and undertaken with olivine (e.g., Schuiling and Krijgsman, 2006; ten Berge et al., 2012) and wollastonite minerals (e.g., Dudhaiya et al., 2019; Haque et al., 2019). However, for a typical large mine producing $\sim 10 \mathrm{Mt}$ year $^{-1}$ of tailings, this rate would require tailings distribution over a wide region $\left(2500 \mathrm{~km}^{2}\right)$, which may only be possible in remote areas. Higher application rates, such as 400 or $4000 \mathrm{tha}^{-1}$, would require proportionally smaller but still substantial distribution regions (250 and 25 $\mathrm{km}^{2}$ respectively) and the tailings would become a substantial proportion of the soil $\left(\sim 5-50 \%\right.$ year $\left.^{-1}\right)$ for a $\sim 30 \mathrm{~cm}$ tillage depth. As with all enhanced weathering of mine tailings approaches, soil porewaters need to be monitored to ensure that toxic metals (e.g., $\mathrm{Ni}, \mathrm{Cr}$ ) are not mobilised into the environment or crops.

Engineered solutions for enhancing weathering rates could involve utilising enclosed reactor systems or heap leaching (Darton and Yang, 2020; Hamilton et al., 2020; Xing et al., 2021). For on-site operations and reactor-based weathering systems, several mine-specific considerations need to be addressed for successful deployment in addition to the chemical and kinetic barriers to implementation. The spatial requirements for such schemes need to be carefully considered, as well as their water and energy requirements, the destination of any discharged liquid or solid outputs, and the resultant environmental, economic and societal considerations.

\section{DATA AVAILABILITY STATEMENT}

The original contributions presented in the study are included in the article/Supplementary Material, further inquiries can be directed to the corresponding author.

\section{AUTHOR CONTRIBUTIONS}

All authors listed have made a substantial, direct and intellectual contribution to the work, and approved it for publication.

\section{FUNDING}

The GGREW project (NE/P019536/1) is supported by NERC, the Engineering \& Physical Sciences Research Council (EPSRC), the Economic \& Social Research Council (ESRC), and the Department for Business, Energy \& Industrial Strategy (BEIS), with in-kind contributions from the Met Office 
Hadley Centre and the Science \& Technology Facilities Council (STFC).

\section{ACKNOWLEDGMENTS}

We thank Dr. Jude Coggon (University of Southampton) for assistance with drafting Figure 4. LB would like to thank Prof.

\section{REFERENCES}

Aachener Stiftung (2011). Aachener Stiftung Kathy Beys Factsheet Measuring Resource Extraction. Available online at: https://www.aachener-stiftung. de/fileadmin/ASKB/Media/Factsheet_Measuring_Resource_Extraction.pdf (accessed March 1, 2021).

Alcalde, J., Flude, S., Wilkinson, M., Johnson, G., Edlmann, K., Bond, C. E., et al. (2018). Estimating geological $\mathrm{CO}_{2}$ storage security to deliver on climate mitigation. Nat. Commun. 9:2201. doi: 10.1038/s41467-018-04 423-1

Andrews, M. G., and Taylor, L. L. (2019). Combating climate change through enhanced weathering of agricultural soils. Elements 15, 253-258. doi: 10.2138/gselements.15.4.253

Azadi, M., Northey, S. A., Ali, S. H., and Edraki, M. (2020). Transparency on greenhouse gas emissions from mining to enable climate change mitigation. Nat. Geosci. 13, 100-104. doi: 10.1038/s41561-020-0531-3

Azdarpour, A., Asadullah, M., Mohammadian, E., Hamidi, H., Junin, R., and Karaei, M. A. (2015). A review on carbon dioxide mineral carbonation through pH-swing process. Chem. Eng. J. 279, 615-630. doi: 10.1016/j.cej.2015.05.064

Bandstra, J. Z., Buss, H. L., Campen, R. K., Liermann, L. J., Moore, J., Hausrath, E. M., et al. (2008). "Appendix: Compilation of mineral dissolution rates," in Kinetics of Water-Rock Interaction, eds. S. L. Brantley, J. D. Kubicki and A. F. White (New York: Springer), 737-823.

Beerling, D. J., Kantzas, E. P., Lomas, M. R., Wade, P., Eufrasio, R. M., Renforth, P., et al. (2020). Potential for large-scale $\mathrm{CO}_{2}$ removal via enhanced rock weathering with croplands. Nature 583, 242-248. doi: 10.1038/s41586-020-2448-9

Bodénan, F., Bourgeois, F., Petiot, C., Aug,é, T., Bonfils, B., Julcour-Lebigue, C., et al. (2014). Ex situ mineral carbonation for $\mathrm{CO}_{2}$ mitigation: Evaluation of mining waste resources, aqueous carbonation processability and life cycle assessment (Carmex project). Miner. Eng. 59, 52-63. doi: 10.1016/j.mineng.2014.01.011

Bufe, A., Hovius, N., Emberson, R., Rugenstein, J. K. C., Galy, A., HassenruckGudipati, H. J., et al. (2021). Co-variation of silicate, carbonate and sulfide weathering drives $\mathrm{CO}_{2}$ release with erosion. Nat. Geosci. 14, 211-216. doi: 10.1038/s41561-021-00714-3

Canadell, J. G., Le Quér,é, C., Raupach, M. R., Field, C. B., Buitenhuis, E. T., Ciais, P., et al. (2007). Contributions to accelerating atmospheric $\mathrm{CO}_{2}$ growth from economic activity, carbon intensity, and efficiency of natural sinks. Proc. Natl. Acad. Sci. U.S.A. 104, 18866-18870. doi: 10.1073/pnas.0702737104

Cherlet, M., Hutchinson, C., Reynolds, J., Hill, J., Sommer, S., and von Maltitz, G. (2018). World Atlas of Desertification. Luxembourg: Publication Office of the European Union.

Corti, G., Weindorf, D. C., Fernandez Sanjurjo, M. J., and Cacovean, H. (2012). Use of waste materials to452 improve soil fertility and increase crop quality and quantity. Appl. Environ. Soil Sci. 2012:204914 doi: 10.1155/2012/2 04914

Darton, R. C., and Yang, A. (2020). "Removing carbon dioxide from the air to stabilise the climate," in Advances in Carbon Management Technologies, eds. S. K. Sidkar and F. Priciotta (Boca Raton: CRC Press), 3-22.

Dudhaiya, A., Haque, F., Fantucci, H., and Santos, R. M. (2019). Characterization of physically fractionated wollastonite-amended agricultural soils. Minerals 9:635. doi: 10.3390/min9100635

Edwards, D. P., Lim, F., James, R. H., Pearce, C. R., Scholes, J., Freckleton, R. P., et al. (2017). Climate change mitigation: potential benefits and pitfalls
Aidong Yang, Prof. Richard Darton, Dr. Manon Duret and Dr. Phyllis Lam for their help with the manuscript preparation.

\section{SUPPLEMENTARY MATERIAL}

The Supplementary Material for this article can be found online at: https://www.frontiersin.org/articles/10.3389/fclim. 2021.694175/full\#supplementary-material

of enhanced rock weathering in tropical agriculture. Biol. Lett. 13:20160715. doi: $10.1098 / \mathrm{rsbl} .2016 .0715$

Field, C. B., and Raupach, M. R. (2004). The Global Carbon Cycle: Integrating Humans, Climate and the Natural World. Washington, DC: Island Press.

Freedonia (2019). World Tungsten. Available online at: https://www. freedoniagroup.com/industry-study/world-tungsten-3306.htm (accessed March 1, 2021).

Gbor, P. K., and Jia, C. Q. (2004). Critical evaluation of coupling particle size distribution with the shrinking core model. Chem. Eng. Sci. 59, 1979-1987. doi: 10.1016/j.ces.2004.01.047

Hamilton, J. L., Wilson, S. A., Morgan, B., Harrison, A. L., Turvey, C. C., Paterson, D. J., et al. (2020). Accelerating mineral carbonation in ultramafic mine tailings via direct $\mathrm{CO}_{2}$ reaction and heap leaching with potential for base metal enrichment and recovery. Econ. Geol. 115, 303-323. doi: 10.5382/econgeo.4710

Hangx, S. J. T., and Spiers, C. J. (2009). Coastal spreading of olivine to control atmospheric $\mathrm{CO}_{2}$ concentrations: a critical analysis of viability. Int. J. Greenhouse Gas Control 3, 757-767. doi: 10.1016/j.ijggc.2009.07.001

Haque, F., Santos, R. M., Dutta, A., Thimmanagari, M., and Chiang, Y. W. (2019). Co-benefits of wollastonite weathering in agriculture: $\mathrm{CO}_{2}$ sequestration and promoted plant growth. ACS Omega 4, 1425-1433. doi: 10.1021/acsomega.8b02477

Harrison, A. L., Power, I. M., and Dipple, G. M. (2013). Accelerated carbonation of brucite in mine tailings for carbon sequestration. Environ. Sci. Technol. 47, 126-134. doi: 10.1021/es3012854

Hartmann, J., West, A. J., Renforth, P., Köhler, P., De La Rocha, C. L., Wolf-Gladrow, D. A., et al. (2013). Enhanced chemical weathering as a geoengineering strategy to reduce atmospheric carbon dioxide, supply nutrients, and mitigate ocean acidification. Rev. Geophys. 51, 113-149. doi: $10.1002 /$ rog.20004

Hayhurst, A. (1974). "Crystallization processes in a high carbon ferrochromium slag," in Proceedings of the First International Ferroalloys Congress (Johannesburg), 187-193.

Hitch, M., Ballantyne, S. M., and Hindle, S. R. (2010). Revaluing mine waste rock for carbon capture and storage. Int. J. Min. Reclamat. Environ. 24, 64-79. doi: 10.1080/17480930902843102

Horii, K., Kitano, Y., Tsutsumi, N., and Kato, T. (2013). Processing and Reusing Technologies for Steelmaking Slags. Nippon Steel Report 104, Tokyo, Japan, pp 123-129.

Huntzinger, D. N., Gierke, J. S., Kawatra, S., Eisele, T., and Sutter, L. L. (2009). Carbon dioxide sequestration in cement kiln dust through mineral carbonation. Environ. Sci. Technol. 43, 1986-1992. doi: 10.1021/es802910z

IPCC (Intergovernmental Panel on Climate Change) (2014). Climate Change 2013: The Physical Science Basis. Working Group I Contribution to the Fifth Assessment Report of the Intergovernmental Panel on Climate Change. Geneva: IPCC.

Kay, A. (2018). Stripping ratios: What are they and why are they important? INN Copper Investing News. Available online at: https://investingnews.com/ daily/resource-investing/base-metals-investing/copper-investing/strip-ratiowestern-copper-gold-nemaska-lithium (accessed March 1, 2021).

Kelemen, P. B., McQueen, N., Wilcox, J., Renforth, P., Dipple, G., and Vankeuren, A. P. (2020). Engineered carbon mineralization in ultramafic rocks for $\mathrm{CO}_{2}$ removal from air: review and new insights. Chem. Geol. 550:119628. doi: 10.1016/j.chemgeo.2020.119628

Kesler, S. E., and Simon, A. C. (2015). Mineral Resources, Economics and the Environment, 2nd Edition. Cambridge: Cambridge University Press. 
Kheshgi, H. S. (1995). Sequestering atmospheric carbon dioxide by increasing ocean alkalinity. Energy 20, 915-922. doi: 10.1016/0360-5442(95)00035-F

Koomson, B., and Asiam, E. K. (2013). Studies on arsenic release and its mitigation from tailings dam using nanomagnetite particles. Ghana Min. J. 14, 66-69.

KPMG (2018). KPMG Commodity Insights Bulletin-Chromite. Available online at: https://assets.kpmg/content/dam/kpmg/xx/pdf/2018/11/kpmg-commodityinsights-bulletin-chromite.pdf (accessed March 1, 2021).

Kremer, D., Etzold, S., Boldt, J., Blaum, P., Hahn, K. M., Wotruba, H., et al. (2019). Geological mapping and characterization of possible primary input materials for the mineral sequestration of carbon dioxide in Europe. Minerals 9:485. doi: $10.3390 / \min 9080485$

Lackner, K. S., Wendt, C. H., Butt, D. P., Joyce, E. L., and Sharp, D. H. (1995). Carbon dioxide disposal in carbonate minerals. Energy 20, 1153-1170. doi: 10.1016/0360-5442(95)00071-N

Lapakko, K. A., Engstrom, J. N., and Antonson, D. A. (2006). "Effects of particle size on drainage quality from three lithologies," in 7th International Conference on Acid Rock Drainage 2006, vol 2, $1026-1050$.

Li, J., Hitch, M., Power, I. M., and Pan, Y. (2018). Integrated mineral carbonation of ultramafic mine deposits-a review. Minerals 8:147. doi: 10.3390/min804 0147

Marieni, C., Matter, J., and Teagle, D. A. H. (2020). Experimental study on mafic rock dissolution rates within $\mathrm{CO}_{2}$-seawater-rock systems. Geochim. Cosmochim. Acta 272, 259-275. doi: 10.1016/j.gca.2020.01.004

Martinez, A. M., Rubin, J. B., Hollis, W. K., Ziock, L. H. J., Guthrie, G. D., Chipera, S. J., et al. (2000). "Sequestration of carbon dioxide by carbonation of minerals at supercritical fluid conditions," in Mexican American Engineers Scientists 26th Annual International Symposium, 2800.

McCutcheon, J., Dipple, G. M., Wilson, S. A., and Southam, G. (2015). Production of magnesium-rich solutions by acid leaching of chrysotile: a precursor to field-scale deployment of microbially enabled carbonate mineral precipitation. Chem. Geol. 413, 119-131. doi: 10.1016/j.chemgeo.2015.08.023

McCutcheon, J., Turvey, C., Wilson, S. A., Hamilton, J. L., and Southam, G. (2017). Experimental deployment of microbial mineral carbonation at an asbestos mine: potential applications to carbon storage and tailings stabilization. Minerals 7:191. doi: 10.3390/min7100191

McCutcheon, J., Wilson, S. A., and Southam, G. (2016). Microbially accelerated carbonate mineral precipitation as a strategy for in situ carbon sequestration and rehabilitation of asbestos mine sites. Environ. Sci. Technol. 50, 1419-1427. doi: 10.1021 /acs.est.5b04293

McNab, B. (2006). "Exploring HPGR technology for heap leaching of fresh rock gold ores," in IIR Crushing and Grinding Conference, March 29-30, Townsville, Australia.

Mervine, E. M., Wilson, S. A., Power, I. M., Dipple, G. M., Turvey, C. C., and Hamilton, J. L. (2018). Potential for offsetting diamond mine carbon emissions through mineral carbonation of processed kimberlite: an assessment of De Beers mine sites in South Africa and Canada. Mineral. Petrol. 112, 755-765. doi: 10.1007/s00710-018-0 589-4

Meyer, N. A., Vogeli, J. U., Becker, M., Broadhurst, J. L., Reid, D. L., and Franzidis, J.-P. (2014). Mineral carbonation of PGM mine tailings for $\mathrm{CO}_{2}$ storage in South Africa: a case study. Mineral. Eng. 59, 45-51. doi: 10.1016/j.mineng.2013.10.014

Mining Technology (2019). Tampakan Gold Copper Project. Available online at: https://www.mining-technology.com/projects/tampakangoldcopperpr (accessed March 1, 2021).

Mudd, G. M., and Diesendorf, M. (2008). Sustainability of uranium mining and milling: toward quantifying resources and eco-efficiency. Environ. Sci. Technol. 42, 2624-2630. doi: 10.1021/es702249v

National Academies of Sciences, Engineering, and Medicine (NASEM) (2019). Negative Emissions Technologies and Reliable Sequestration: A Research Agenda. Washington DC: The National Academies Press.

Ndlovu, S., Simate, G. S., and Matinde, E. (2017). Waste Production and Utilization in the Metal Extraction Industry. Boca Raton: CRC Press, Taylor and Francis Group.

Pacala, S., and Socolow, R. (2004). Stablization wedges: solving the climate problem for the next 50 years with current technologies. Science 305, 968-972. doi: $10.1126 /$ science. 1100103
Palandri, J. L., and Kharaka, Y. K. (2004). A Compilation of Rate Parameters of Water-Mineral Interaction Kinetics for Application to Geochemical Modelling. U.S. Geological Survey Open File Report 2004-1068.

Pariser, H. H., Backeberg, N. R., Masson, O. C. M., and Bedder, J. C. M. (2018). "Changing nickel and chromium stainless steel markets-market review by Heinz Pariser," in Proceedings of Infacon XV: International Ferro-Alloys Congress, Cape Town (25-28 February, 2018).

Picot, J. C., Cassard, D., Maldan, F., Greffi,é, C., and Bodénan, F. (2011). Worldwide potential for ex-situ mineral carbonation. Energy Proc. 4, 2971-2977. doi: 10.1016/j.egypro.2011.02.206

Power, I. M., Dipple, G. M., Bradshaw, P. M. D., and Harrison, A. L. (2020). Prospects for $\mathrm{CO}_{2}$ mineralization and enhanced weathering of ultramafic mine tailings from the Baptise nickel deposit in British Columbia, Canada. Int. J. Greenhouse Gas Control 94:102895. doi: 10.1016/j.ijggc.2019.102895

Power, I. M., Harrison, A. L., and Dipple, G. M. (2016). Accelerating mineral carbonation using carbonic anhydrase. Environ. Sci. Technol. 50, 2610-2618. doi: 10.1021/acs.est.5b04779

Power, I. M., Harrison, A. L., Dipple, G. M., and Southam, G. (2013). Carbon sequestration via carbonic anhydrase facilitated magnesium carbonate precipitation. Int. J. Greenhouse Gas Control 16, 145-155. doi: 10.1016/j.ijggc.2013.03.011

Power, I. M., McCutcheon, J., Harrison, A. L., Wilson, S. A., Dipple, G. M., Kelly, S., et al. (2014). Strategizing carbon-neutral mines: a case for pilot projects. Minerals 4, 399-436. doi: 10.3390/min4020399

Pronost, J., Beaudoin, G., Tremblay, J., Larachi, F., Duchesne, J., Hébert, R., et al. (2011). Carbon sequestration kinetic and storage capacity of ultramafic mining waste. Environ. Sci. Technol. 45, 9413-9420. doi: 10.1021/es203063a

Rapp, D. (2014). "Anthropogenic influences on climate change," in Assessing Climate Change, ed. D. Rapp (California: Springer) 533-595.

Rau, G. H., Knauss, K. G., Langer, W. H., and Caldeira, K. (2007). Reducing energyrelated $\mathrm{CO}_{2}$ emissions using accelerated weathering of limestone. Energy 32, 1471-1477. doi: 10.1016/j.energy.2006.10.011

Renforth, P. (2019). The negative emission potential of alkaline materials. Nat. Commun. 10:1401. doi: 10.1038/s41467-019-09475-5

Renforth, P., and Henderson, G. (2017). Assessing ocean alkalinity for carbon sequestration. Rev. Geophys. 55, 636-674. doi: 10.1002/2016RG000533

Renforth, P., Jenkins, B. G., and Kruger, T. (2013). Engineering challenges of ocean liming. Energy 60, 442-452. doi: 10.1016/j.energy.2013.08.006

S\&P Global (2019). The Socioeconomic and Environmental Impact of LargeScale Diamond Mining. Trucost Report. Available online at: https://www. spglobal.com/marketintelligence/en/documents/the-socioeconomic-andenvironmental-impact-of-large-scale-diamond-mining_dpa_02-may-2019. pdf (accessed March 1, 2021).

Salek, S. S., Kleerebezem, R., Jonkers, H. M., Witkamp, G.-J. and van Loosdrecht, M. C. M. (2013). Mineral $\mathrm{CO}_{2}$ sequestration by environmental biotechnological processes. Trends Biotechnol. 31, 139-146. doi: 10.1016/j.tibtech.2013.01.005

Schuiling, R. D., and Krijgsman, P. (2006). Enhanced weathering: an effective and cheap tool to sequester $\mathrm{CO}_{2}$. Clim. Change 74, 349-354. doi: 10.1007/s10584-005-3485-y

Sedumedi, H. N., Mandiwana, K. L., Ngobeni, P., and Panichev, N. (2009). Speciation of Cr (VI) in environmental samples in the vicinity of the ferrochrome smelter. J. Hazard. Mater. 172, 1686-1689. doi: 10.1016/j.jhazmat.2009.07.111

Statista (2020). Energy and Environment. Statistics and Market Data on Energy and environment. Available online at: https:/www.statista.com/markets/408/ energy-environment (accessed March 1, 2021).

Steinour, H. H. (1959). Some effects of carbon dioxide on mortars and concretediscussion. J. Am. Concr. 30, 905-907.

Strefler, J., Amann, T., Bauer, N., Kriegler, E., and Hartmann, J. (2018). Potential and costs of carbon dioxide removal by enhanced weathering of rocks. Environ. Res. Lett. 13:034010. doi: 10.1088/1748-9326/aaa9c4

ten Berge, H. F. M., van der Meer, H. G., Steenhuizen, J. W., Goedhart, P. W., Knops, P., and Verhagen, J. (2012). Olivine weathering in soil, and its effects on growth and nutrient uptake in ryegrass (Lolium perenne L.): a pot experiment. PLoS ONE 7:e42098. doi: 10.1371/journal.pone.0042098

Thenepalli, T., Chilakala, R., Habte, L., Tuan, L. Q., and Kim, C. S. (2019). A brief note on the heap leaching technologies for the recovery of valuable metals. Sustainability 11:3347. doi: 10.3390/su11123347 
Torres, M. A., West, A. J., and Li, G. (2014). Sulphide oxidation and carbonate dissolution as a source of $\mathrm{CO}_{2}$ over geological timescales. Nature 507, 346-349. doi: $10.1038 /$ nature 13030

United Nations Environment Programme (UNEP) (2017). The Emissions Gap Report 2017. Nairobi: UNEP.

United States Geological Survey (USGS) (2021). Mineral Commodity Summaries 2021. Reston, VA: U.S. Geological Survey.

Vance, D., Teagle, D. A. H., and Foster, G. L. (2009). Variable Quaternary chemical weathering fluxes and imbalances in marine geochemical budgets. Nature 458, 493-496. doi: 10.1038/nature07828

Vogeli, J., Reid, D. L., Becker, M., Broadhurst, J., and Franzidis, J.-P. (2011). Investigation of the potential for mineral carbonation of PGM tailings in South Africa. Miner. Eng. 24, 1348-1356. doi: 10.1016/j.mineng.2011. 07.005

White, A. F., Blum, A. E., Schulz, M. S., Bullen, T. D., Harden, J. W., and Peterson, M. L. (1996). Chemical weathering of a soil chronosequence on granitic alluvium: 1. Reaction rates based on changes in soil mineralogy. Geochim. Cosmochim. Acta 60, 2533-2550. doi: 10.1016/0016-7037(96)0 0106-8

Wilcox, J., Kolosz, B., and Freeman, J. (2021). CDR Primer. Available online at: https://cdrprimer.org/ (accessed March 1, 2021).

Wilson, S. A., Dipple, G. M., Power, I. M., Thom, J. M., Anderson, R. G., Raudsepp, M., et al. (2009). Carbon dioxide fixation within mine wastes of ultramafichosted ore deposits: examples from the Clinton Creek and Cassiar chrysotile deposits, Canada. Econ. Geol. 104, 95-112. doi: 10.2113/gsecongeo.104.1.95

Wilson, S. A., Harrison, A. L., Dipple, G. M., Power, I. M., Barker, S. L. L., Mayer, K. U., et al. (2014). Offsetting of $\mathrm{CO}_{2}$ emissions by air capture in mine tailings at the Mount Keith Nickel Mine, Western Australia: rates, controls and prospects for carbon neutral mining. Int. J. Greenh. Gas Con. 25, 121-140. doi: 10.1016/j.ijggc.2014. 04.002

World Bank Group (2017). The Growing Role of Minerals and Metals for a Low Carbon Future. Washington D.C: World Bank Publications.

Xing, L., Darton, R. C., and Yang, A. (2021). Enhanced weathering to capture atmospheric carbon dioxide: Modeling of a trickle-bed reactor. AIChE J. 67:e17202. doi: 10.1002/aic. 17202
Zanbak, C. (2012). Heap Leaching Technique in Mining Within the Context of Best Available Technologies (BAT). Euromines Report, The European Association of Mining Industries, Metal Ores and Industry Minerals. Available online at: http://www.euromines.org/files/mining-europe/mining-techniques/ batforheapleaching-feb2013-c.zanbak-euromines.pdf (accessed March 1, 2021).

Zevenhoven, R., and Kohlmann, J. (2001). " $\mathrm{CO}_{2}$ sequestration by magnesium silicate mineral carbonation in Finland," in Second Nordic Mini-symposium on Carbon Dioxide Capture and Storage, Göteborg.

Zhang, R., Hedrich, S., Römer, F., Goldmann, D., and Schippers, A. (2020a). Bioleaching of cobalt from $\mathrm{Cu} / \mathrm{Co}$-rich sulfidic mine tailings from the polymetallic Rammelsberg mine, Germany. Hydrometallurgy 197:105443. doi: 10.1016/j.hydromet.2020.105443

Zhang, R., Yi, L., Huang, Z., Cai, W., and Jiang, Z. (2020b). Highly efficient beneficiation of low-grade iron ore via ore-coal compositefed rotary kiln reduction: pilot-scale study. JOM 72, 1680-1686. doi: $10.1007 /$ s11837-020-04053-3

Conflict of Interest: The authors declare that the research was conducted in the absence of any commercial or financial relationships that could be construed as a potential conflict of interest.

Publisher's Note: All claims expressed in this article are solely those of the authors and do not necessarily represent those of their affiliated organizations, or those of the publisher, the editors and the reviewers. Any product that may be evaluated in this article, or claim that may be made by its manufacturer, is not guaranteed or endorsed by the publisher.

Copyright (c) 2021 Bullock, James, Matter, Renforth and Teagle. This is an open-access article distributed under the terms of the Creative Commons Attribution License (CC $B Y)$. The use, distribution or reproduction in other forums is permitted, provided the original author(s) and the copyright owner(s) are credited and that the original publication in this journal is cited, in accordance with accepted academic practice. No use, distribution or reproduction is permitted which does not comply with these terms. 